\title{
Using Authentic Assessment to Measure Basic English Speaking Skill of Students Majoring in Japanese Study
}

\author{
Lenggahing Asri Dwi Eko Saputri \\ Program Studi D4 Bahasa Asing Terapan, Sekolah Vokasi, Universitas Diponegoro, \\ Jl. Prof. Soedarto, SH, Kampus Undip Tembalang, Semarang, Indonesia \\ *Corresponding Author.Tel+6285640048611 \\ Email: lenggahingasri@live.undip.ac.id
}

\begin{abstract}
This study aims at describing the implementation of authentic assessment to measure Basic English speaking skill of students majoring in Japanese study. The description consists of three parts, namely designing the authentic assessment, implementing the authentic assessment and scoring students'speaking skill. This study applies qualitative descriptive method. The data was collected through class observation. The result of the study revealed that authentic assessment was considered as the most effective way in assessing students' performance in the classroom as its ability to assess the whole process of learning rather than just testing students' knowledge at the end of the course. In conducting the authentic assessment to measure Basic English speaking skill of students majoring in Japanese study, the lecturer designed the authentic assessment based on the six steps suggested by Pierce and O'Malley (1996), implemented performance assessment to measure the students speaking skill and used analytic rubric in scoring the students speaking skill.
\end{abstract}

Keywords: authentic assessment, Basic English, Speaking skill, students majoring in Japanese study

\section{Introduction}

Based on the curriculum of Applied Foreign Language program, the $3^{\text {rd }}$ semester students majoring in Japanese study are required to take Basic English course. This course itself will be based on tourism in accordance with the vision of the Applied Foreign Language program that is not only to give the students the competence of mastering English and Japanese languages but also give them the competence of tourism and hospitality.

In giving the lesson to the students majoring in Japanese study, the lecturer used the authentic assessment to measure their Basic English speaking skill. Authentic assessment is the multiple forms of assessment that reflect student learning, achievement, motivation and attitudes on instructionally-relevant classroom activities (O’Malley \& Pierce, 1996).

To implement authentic assessment, there are some crucial points that have to be understood. First of all, lecturer has to be able to design authentic assessment as suitable as possible to students and learning objectives.

Furthermore, lecturer should determine the type of authentic assessment that will be used to measure the students' English skill. In addition, another crucial point which should be understood is about scoring of authentic assessment. Authentic assessment can be scored by using rubrics, rating scale, and checklist (Nitko, 2001). 
Tersedia online di http://ejournal.undip.ac.id/index.php/kiryoku

Assessment of speaking should focus on student's ability to interpreted and convey meaning for authentic purpose in interactive context. Lecturers need to use assessment task that are as authentic as possible in a classroom setting. This means (1) using authentic language in speaking, (2) setting real world task, (3) giving student's opportunities to use language in situation based on everyday life. It is important to expose students to authentic language and help them work out strategies for dealing with less than total comprehension (Porter and Roberts, 1987). Pierce and O'Malley (1996) provide some steps in preparing speaking assessment:

1. Identifying purpose

2. Planning for assessment

3. Developing scoring procedures

4. Setting standard

5. Selecting assessment activities

6. Recording information

A related investigation about the implementation of authentic assessment has been conducted by other researcher. Al Fama (2015) conducted a research which focused on the implementation of authentic assessment in teaching writing.

His findings showed that the lecturers' knowledge and their experience influence the implementation of authentic assessment. The lecturers who had sufficient knowledge about the nature and the various types of authentic assessment has proper implementation of authentic assessment in teaching writing.

The research also revealed that authentic assessments provide feedback on a student's learning to encourage further development. It can improve students' knowledge, deep understanding, problemsolving skills, social skills, and attitudes that are used in a simulation of a realworld situation. This study had been exposed the implementation of authentic assessment, but it only focused on one Copyright @ 2021, Kiryoku: Jurnal Studi Kejepangan, e-ISSN:2581-0960p-ISSN: 2599-0497
English productive skill that was the implementation of authentic assessment in teaching writing.

Different from the previous study which focused on the implementation of authentic assessment in teaching writing, the present study would be focused on the implementation of authentic assessment in teaching speaking, especially in the use of authentic assessment to measure Basic English speaking skill of students majoring in Japanese Study.

\section{Methods}

It is essential to apply a proper research method in order to attain research objectives. Since the present study was focused on describing the implementation of authentic assessment, qualitative descriptive method was appropriate to be employed in this study.

The object of the study was the process of implementing authentic assessment in the form of performance assessment to measure Basic English speaking skill of students majoring in Japanese study.

Collecting data is essential part in conducting research. In this research, class observation was applied to obtain the data. It was conducted to obtain the teaching and learning activities in the classroom especially on how the lecturer implemented the authentic assessment to measure Basic English speaking skill of students majoring in Japanese study.

\section{Result and Discussion}

The use of authentic assessment to measure Basic English speaking skill of students majoring in Japanese Study consisted of three parts, namely designing the authentic assessment, implementing the 
authentic assessment and scoring students' speaking skill.

\subsection{Designing the Authentic Assessment}

The lecturer designed the authentic assessment to measure Basic English speaking skill of students majoring in Japanese Study based on the six steps suggested by Pierce and O'Malley (1996) that are identifying purpose, planning for assessment, developing scoring procedures, setting standard, selecting assessment activities and recording information.

The steps were implemented in the speaking activity of every unit. There were four units in Basic English lesson namely namely An Introduction to Travel and Tourism; Tourism Organizations Promotion and Marketing; Types of Transport; and Accommodation.

Besides conducting the steps in planning and designing authentic assessment suggested by Pierce and O'Malley (1996), the lecturer also determined performance assessment as the type of authentic assessment in measuring Basic English speaking skill of students majoring in Japanese Study. As its name, it assesses activities or tasks which students demonstrate through performance in real situation. In this way, the lecturer should be able to create more meaningful, practical, realistic and performanceoriented tasks.

Performance assessment may consist of any form of assessment in which the student constructs a response orally for examples are oral reports, role playing, panel discussion, plays and other demonstration (Marsh \& Wills, 2007; O' Malley \& Pierce, 1996). They may vary in the length of time to complete the tasks. For example a simple oral report may only take one period/ meeting of lesson. On the other hand, some complicated task such as plays may take several weeks and need extra time for preparation, investigation, practice and presentation.

Furthermore, the lecturer also decided the technique of scoring authentic assessment. An analytic rubric was chosen as the technique in scoring Basic English speaking skill of students majoring in Japanese Study.

\subsection{Implementing the Authentic Assessment}

The implementation of the authentic assessment in every unit was focused on the speaking activity in the form of performance assessment and scored by analytic rubric.

\subsubsection{An Introduction to Travel and Tourism}

Before starting the speaking activity in this unit, the lecturer gave some preparation to the students such as the vocabularies and expressions that they can use in doing a conversation between travel agent and customer. They got the vocabularies of tourism industry and related jobs from reading activity. Furthermore, they got the examples of expressions about exchanging information in a travel agency from listening activity.

In doing the performance assessment on the speaking activity, the lecturer asked the students to work in pair and did a role play. The first student became a travel agent and he or she should ask the customer about what kind of holiday the customer wants this year. Whereas, the second student became a customer and he or she should answer the questions from the travel agent about what kind of holiday he or she wants this year. 
Tersedia online di http://ejournal.undip.ac.id/index.php/kiryoku

\subsubsection{Touris m Organizations Promotion and Marketing}

In this unit, the students also obtained some preparation before starting the speaking activity. First, the lecturer asked them to read a reading text contained detailed information about online tourism marketing. After that, they are asked to listen a radio promotion in promoting some tourism objects.

In doing the performance assessment on the speaking activity the lecturer divided the students in small groups consisted of 4 people and asked them to give a presentation about a holiday destination. Their presentation should contain the information as follows:

1. Transportations that can be used by the tourists to reach the destination

2. Facilities and services that tourists can get in the destination

3. Accommodations and culinary that tourists can enjoy in the destination

\subsubsection{Types of Transport}

The students got some preparation before starting the speaking activity in this unit as well. They are asked to read a reading activity to obtain the information about types of transport that can be used by tourists. Next, the students were asked to listen a telephone conversation at the ticket office between a customer and a ticket officer.

In doing the performance assessment on the speaking activity, the lecturer asked the students to work in pair and did a role play. The first student became a customer and he or she should buy a ticket. Whereas, the second student became a ticket officer and he or she should asked about the detail of the customer order included where and when he or she wants to go and the personal identity of the customer.

\subsubsection{Accommodation}

Similar with the other units, the students also got some preparation before doing the speaking activity in this unit. First, the lecturer asked the students to read a reading text containing the information about types of accommodation that can be enjoyed by tourist such as hotel, motel, guesthouse, villa and etc. The reading text also explained the services provided by each type of accommodation. Second, the students were asked to listen a telephone conversation between a hotel guest and a receptionist asking and answering about different services in the hotel.

In doing the performance assessment on the speaking activity, the lecturer asked the students to work in pair and did a role play. The first student became a hotel guest and he or she should ask the receptionist about different services such as complimentary toiletries, internet access, ironing service, laundry service and etc. and specific information about the service while the second student became a receptionist and he or she should answer the questions from the hotel guest and explain available service in the hotel.

\subsection{Scoring students' speaking skill}

Besides conducting the steps in planning and designing authentic assessment, the lecturer also determine the technique of scoring authentic assessment. There are several techniques in scoring an authentic assessment, namely rubrics, rating scale, and checklist (Nitko, 2001). The lecturers chose to use rubric in scoring their students' authentic assessment. Rubric is scoring guide, consisting of specific preestablished performance criteria, used in evaluating student work on authentic assessments (Mertler, 2001). Rubrics are typically the specific form of scoring instrument used when evaluating student Copyright @ 2021, Kiryoku: Jurnal Studi Kejepangan, e-ISSN:2581-0960p-ISSN: 2599-0497 133 
performances or products resulting from an authentic task.

There are two types of rubrics: holistic and analytic. A holistic rubric requires the lecturer to score the overall process or product as a whole, without judging the component parts separately. In contrast, with an analytic rubric, the lecturer scores separate, individual parts of the product or performance first, then sums the individual scores to obtain a total score (Nitko, 2001). Prior to designing a specific rubric, a lecturer must decide whether the performance or product will be scored holistically or analytically (Airasian, 1999). The lecturer decided to use analytic rubric because formative feedback is the goal. It is important to note that one type of rubric is not inherently better than the other-you must find a format that works best for your purposes (Montgomery, 2001).

The rubric that used by the lecturer in measuring students' speaking skill is as follow:

\begin{tabular}{|c|c|c|}
\hline ASPECT & INFORMATION & SCORE \\
\hline \multirow{4}{*}{ Pronunciation } & $\begin{array}{l}\text { - Very clear so easy to } \\
\text { understand. }\end{array}$ & $22-25$ \\
\hline & $\begin{array}{l}\text { Easily understood } \\
\text { despite the influence of } \\
\text { the mother tongue can be } \\
\text { detected. }\end{array}$ & $18-21$ \\
\hline & $\begin{array}{l}\text { - There are } \\
\text { pronunciation problems } \\
\text { so that listeners need full } \\
\text { concentration. }\end{array}$ & $14-17$ \\
\hline & $\begin{array}{l}\text { - There are serious } \\
\text { pronunciation problems } \\
\text { that cannot be understood. }\end{array}$ & $10-13$ \\
\hline \multirow[t]{4}{*}{ Grammar } & $\begin{array}{l}\text { - No or few } \\
\text { grammatical errors. }\end{array}$ & $22-25$ \\
\hline & $\begin{array}{l}\text { - Sometimes there is a } \\
\text { mistake but does not } \\
\text { affect the meaning. }\end{array}$ & $18-21$ \\
\hline & $\begin{array}{l}\text { Often make mistakes } \\
\text { making the meaning } \\
\text { hardly comprehensible. }\end{array}$ & $14-17$ \\
\hline & $\begin{array}{l}\text { - Solecism so badly } \\
\text { that it could not be } \\
\text { understood. }\end{array}$ & $10-13$ \\
\hline
\end{tabular}

\begin{tabular}{|c|c|c|}
\hline \multirow[t]{4}{*}{ Vocabulary } & $\begin{array}{l}\text { - Using the appropriate } \\
\text { vocabulary and } \\
\text { expressions. }\end{array}$ & $22-25$ \\
\hline & $\begin{array}{l}\text { - Sometimes using less } \\
\text { precise vocabularies and } \\
\text { should be explained } \\
\text { again. }\end{array}$ & $18-21$ \\
\hline & $\begin{array}{l}\bullet \quad \text { Often using } \\
\text { inappropriate } \\
\text { vocabularies. }\end{array}$ & $14-17$ \\
\hline & $\begin{array}{l}\text { Vocabulary is very } \\
\text { limited so that the } \\
\text { conversation cannot be } \\
\text { happening. }\end{array}$ & $10-13$ \\
\hline \multirow[t]{4}{*}{ Fluency } & - Very fluent. & $22-25$ \\
\hline & $\begin{array}{l}\text { - Fluency is slightly } \\
\text { disturbed by the language } \\
\text { problem. }\end{array}$ & $18-21$ \\
\hline & $\begin{array}{l}\text { - Often hesitated and } \\
\text { stalled because of the } \\
\text { language limitations. }\end{array}$ & $14-17$ \\
\hline & $\begin{array}{l}\text { - Talk disjointed and } \\
\text { stopped so that the } \\
\text { conversation can not be } \\
\text { happening. }\end{array}$ & $10-13$ \\
\hline
\end{tabular}

Chart 1. Rubric for assessing speaking skills

\section{Conclusions}

Assessment is an integral part of teaching and learning process since assessment encompassed the success of teaching and learning. Assessment aims to educate and improve students' performance. Hence, assessment is not only as a means to measure students' outcome through conducting several tests. On the other hand, it has to help students to perform well in the assessment process. Thus, authentic assessment was considered as the most effective way in assessing students' performance in the classroom as its ability to assess the whole process of learning rather than just testing students' knowledge at the end of the course.

In conducting the authentic assessment to measure Basic English speaking skill of students majoring in Japanese study, the lecturer designed the authentic assessment based on the six steps suggested by Pierce 
Tersedia online di http://ejournal.undip.ac.id/index.php/kiryoku

and O’Malley (1996), implemented performance assessment to measure the students speaking skill and used analytic rubric in scoring the students speaking skill.

\section{References}

Al Fama, Y.A.A. Masaud. 2015. The Implementation of Authentic Assessment in Teaching Writing. Tesis Magister Pendidikan Universitas Sebelas Maret Surakarta.

Airasian, P. W. 1991. Classroom Assessment. New York: McGraw Hill.

Baker, E.L. 1993. Questioning the Technical Quality of Performance Assessment. The School Administrator 50 (11):12-16.

Bailey. 2009. Languange teacher supervision. In A. Burns and J.C. Richards (eds), Second Language Teacher Education. pp. 269 - 278. New York: Cambridge University Press.

Brown, H Douglas. 2001. Teaching by Principle:An Interactive Approach to Language Pedagogy. New York. Longman.

Brown, H. Douglas. 2007. Principles of Language Learning and Teaching. (5 $5^{\text {th }}$ $E d$.). New York: Longman.

Herman, J.L., P.R Aschbacher, \& L. Winters. 1992. A Practical Guide to Authentic Assessment. Alexandria, Va.: Association For Supervision And Curriculum Development
Hornby, A. S. 2009. Oxford Advanced Learner's Dictionary. Oxford: Oxford University Press

Mertler, Craig A. 2001. Designing scoring rubrics for your classroom. Practical Assessment, Research \& Evaluation, 7(25).

Morris, C. E. (2012). Flash on English for tourism. ELI.

Mueller, Jon. 2005. Authentic Assessment Toolbox: Enhancing Student Learning Through Online Faculty Development. Merlot: Journal of online learning and teaching. (Vol. 1, No. 1)

Nitko, Anthony J. 1983. Educational Test and Measurement: An Introduction. New York: Harcourt Base Jovanovich

O’Malley, J. Michael \& Pierce, Lorraine V. 1996. Authentic Assessment for English Language Learners: Practical Approaches for Teachers. Massachusetts: Addison Wesley Publishing Company

Trisanti, Novita. 2014. EnglishTeacher's Perspective on Authentic Assessment Implementation of Curriculum. Proceedings The 61 ${ }^{\text {st }}$ TEFLIN International Conference. Surakarta: Sebelas Maret University Press

Wiggins, GP. 1993. Assessing Students' Performance. San Francisco: Jossey bass publisher. P. 229

Wiggins, G. P. 1998. Educative Assessment: Designing Assessments to Inform and Improve Students' Performance. San Francisco: Jossey-Bass 